\title{
Use of Garlic Processing By-Products to Remove Pollutants from Aqueous Media
}

\author{
Ildar G. Shaikhiev ${ }^{1 \mathbb{D}}$, Natalia V. Kraysman ${ }^{2, * \mathbb{D}}$, Svetlana V. Sverguzova ${ }^{3 \mathbb{D}}$ \\ 1 Department of Engineering Ecology, Institute of Chemical Engineering and Technology, Kazan National Research \\ Technological University, Kazan, Russian Federation; ildars@inbox.ru (I.G.S.); \\ 2 Department of Foreign Languages for Professional Communication, Institute of Innovation Management, Kazan National \\ Research Technological University, Kazan, Russian Federation; n_kraysman@mail.ru (N.V.K.); \\ 3 Department of Industrial Ecology, Institute of Chemical Engineering and Technology, Belgo-rod State Technological \\ University named after V.G. Shukhov, Belgorod, Russian Federation; pe@intbel.ru (S.V.S.); \\ * Correspondence: n_kraysman@mail.ru (N.V.K.);
}

Scopus Author ID 56114338900

Received: 18.08.2021; Revised: 15.09.2021; Accepted: 17.09.2021; Published: 3.10.2021

\begin{abstract}
The paper summarized the literature data on using ground peels, outer leaves, and garlic roots (Allium sativum L.) as sorption materials to remove various metal ions, dyes, and antibiotics from aqueous media. This paper provides brief information on the amount of waste generated from processing garlic, its chemical composition, and ways of reuse. It gives the adsorption processes parameters and the values of sorption parameters for the studied pollutants. It was shown that garlic residue sorption characteristics for various pollutants could be increased by chemical modification with various chemical reagents. It was determined that the Langmuir model more accurately describes the pollutant's adsorption isotherms in most cases, and the kinetics of the process more accurately describes the pseudo-second-order model. It was shown that garlic peels and steam are good precursors for activated carbons production.
\end{abstract}

Keywords: garlic peel and steam; metal ions; dyes; antibiotics; adsorption; modification.

(C) 2021 by the authors. This article is an open-access article distributed under the terms and conditions of the Creative Commons Attribution (CC BY) license (https://creativecommons.org/licenses/by/4.0/).

\section{Introduction}

The pollution of the World Ocean by various substances is becoming more and more threatening. The source of pollutants entering water bodies is, as a rule, untreated and insufficiently treated wastewater. Various purification methods are used to extract pollutants from wastewater, including mechanical, physicochemical, chemical, and biological. Of all the variety of methods to remove pollutants, adsorption of the latter is a promising method because it allows the minimization of sewage impurities with different initial concentrations in treated water. However, the activated carbons used in practice are expensive; besides, their regeneration contributes to an increase in the cost of cleaning [1].

Currently, to reduce the costs of treatment, an innovative environmental protection trend is being intensively developed in the world community - the use of various industrial wastes as reagents to remove pollutants from water environments [2-11].

Of particular interest are cheap, annually renewable by-products of processing agricultural raw materials, including vegetables. The world literature provides information about the use of by-products of processing vegetables such as cabbage [12], carrots [13, 14], 
tomatoes [15-17], eggplants [18, 19], turnips [20], cucurbits [10] and others as sorption materials.

As shown in [21], onion (Allium cepa) processing waste has good sorption characteristics for dyes, metal ions, and other pollutants. In addition to onions, garlic (Lat. Állium satívum) is also a bulbous vegetable crop that is widely spread throughout the world. It is a perennial herbaceous plant, an Onion species of the Amaryllis (Amaryllidaceae) family of the Onion (Allioideae) subfamily. The bulb is complex and forms in its skins' axils from 2 to 50 ratoons, each covered with hard leathery skins. The bulb is rounded, somewhat flattened, oval-ribbed in the middle, of various colors. With the help of bulbs, garlic reproduces vegetatively. The leaves are solid, narrow, lance-elongated, grooved, with a keel on the lower side, centimeter wide, pointed to the end, whole-edged, erect or drooping, reach $30-100 \mathrm{~cm}$ in length. Each subsequent leaf sprouts from inside the previous one, thereby forming a false stem, more durable than onions [22].

The peduncle (flower-bearing stem, scape) is from 60 to $150 \mathrm{~cm}$ high, dressed with leaf sheaths almost to the half-height, before flowering twists at the end into a spiral and ends with an inflorescence in the form of an umbrella, which is covered with a film membrane before flowering. The inflorescence is a simple spherical umbrella consisting of sterile flowers, aerial propagating bulbs, and a dense blanket (wrapper). The flowers are on long pedicels, with a simple corollaceous perianth consisting of six white petals. The fruit is a capsule [22].

Garlic bulbs contain $35-42 \%$ dry substances, including 6.0-7.9 \% proteins, $7.0-28 \mathrm{mg} \%$ vitamin C (in leaves - up to $80 \mathrm{mg} \%$ ), $0.5 \%$ sugars, $20-27 \%$ polysaccharides. The taste and smell of garlic are due to the presence of essential oil (0.23-0.74\%), which contains allicin and other organic sulfide group compounds (phytoncides). Allicin is an essential oil of garlic, an organic substance that is the strongest antioxidant; that is, it removes free radicals from cells [22].

A bulb of fresh garlic has the following composition (per $100 \mathrm{~g}$ ): water 58-59 g, proteins $-6.2-6.6 \mathrm{~g}$, fats $-0,5 \mathrm{~g}$, carbohydrates $-33.0 \mathrm{~g}$ and vitamins, $\beta$ - carotene $-5 \mathrm{~g}$., thiamin $\left(\mathrm{In}_{1}\right)$

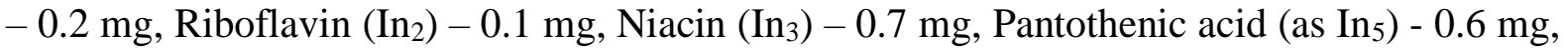
pyridoxine $\left(\operatorname{In}_{6}\right)-1.2 \mathrm{mg}$, folacin $\left(\mathrm{In}_{9}\right)-3 \mu \mathrm{g}$, ascorbic acid $(\mathrm{S})-31 \mathrm{mg}$ [22].

In addition to the above, the following compounds were identified in fresh garlic: pyruvic acid, salicin, sitosterol, caffeic acid, chlorogenic acid, diallyl disulfide, ferulic acid, geraniol, kaempferol linalool, oleanolic acid, coumaric acid, phloroglucinol, phytic acid, quercetin, rutin, allyl cysteine, saponins, stigmasterol, etc. [22].

The largest producer of garlic is China - 21,197,131 tons were grown in 2016. Also, India (1,400,000 tons) and Bangladesh (381,851 tons) are among the three countries leading in garlic production.

Garlic processing by-products include skins, outer leaves, tops, and bottoms. Currently, these materials are disposed of in landfills or used as soil amendments, which result in negative environmental impacts and phytotoxicity to plants, respectively. These materials need to be economically and environmentally managed [23].

They can be used for the production of valuable products [24] such as cellulose [25-27], tannins [28], oligosaccharides [29], allicin [30], inulin [31]. It is proposed to use garlic processing by-products as a substrate for growing mushrooms [32], as a feed additive to improve the quality of laying hens' eggs [33]. Extracts from skins and outer leaves were studied as reagents for reducing corrosion [34], emulsifier [35], antioxidants [36, 37], etc. 
One of the areas of using garlic processing by-products is their use as sorption materials to remove various pollutants from aqueous media.

\section{Removal of Metal Ions with Garlic Processing By-Products}

The presence of compounds containing various functional groupings in the composition of garlic skins and outer leaves, as mentioned above, may contribute to the effective extraction of metal ions [24, 38].

In particular, the adsorption of $\mathrm{Cd}^{2+}$ ions from simulated solutions with an initial concentration of 5, 10, and $20 \mathrm{mg} / \mathrm{g}$ of garlic skin was studied. The highest sorption capacity was determined to be 4.78, 9.43, and $19.64 \mathrm{mg} / \mathrm{g}$ at the above-mentioned starting concentrations, respectively, at a dosage of $1 \mathrm{~g} / \mathrm{dm} 3$, a contact period of 1 hour, and a temperature of $288^{\circ} \mathrm{C}$. It was discovered that the Langmuir model best describes the adsorption isotherms, while the pseudo-second-order model best describes the process kinetics. [57].

For the aim of wastewater treatment, the biosorption of $\mathrm{Cr}(\mathrm{VI})$ by the garlic stem in a batch-type reactor was researched in depth. To maximize $\mathrm{Cr}(\mathrm{VI})$ removal from aqueous solutions and equilibrium isotherms and kinetic data, the effects of initial $\mathrm{Cr}(\mathrm{VI})$ concentration, time, and $\mathrm{pH}$ were explored. From a solution containing $3000 \mathrm{ppm}$ of $\mathrm{Cr}$, the garlic stem adsorption capacity was reported to be $103.09 \mathrm{mg} / \mathrm{g}$ of adsorbent (VI). It can be concluded that the Langmuir adsorption isotherm was more appropriate for explaining equilibrium than the Freundlich adsorption isotherm. Gibbs' free energy was spontaneous for all interactions, and the adsorption process had exothermic enthalpy values [40].

The effects of various experimental conditions on the removal of $\mathrm{Cu}^{2+}$ ions from aqueous solution by garlic skin were investigated. The point of zero charges for garlic skin was between 4.55 to 4.75 . The adsorption capacity of the garlic stem was found to be $66.7 \mathrm{mg} / \mathrm{g}$ at $\mathrm{pH}=5.3$ and $\mathrm{T}=303 \mathrm{~K}$. The pseudo-second-order kinetic model fitted the batch data adequately. The rate constant garlic scale in the absence of diffusional resistance was estimated to be $0.075 \mathrm{mg} / \mathrm{g} / \mathrm{min}$ respectively at $303 \mathrm{~K}$. The thermodynamic studies showed that the $\mathrm{Cu}^{2+}$ ions adsorption on the garlic skin was spontaneous and endothermic [41].

Garlic skin treated with $2 \mathrm{~N} \mathrm{HCl}$ solution was studied to remove $\mathrm{Mn}$ (VII) ions from simulated solutions. It was determined that at the initial Mn(VII) ions concentration of 20-100 ppm, $\mathrm{pH}=5-6$, the sorbent dosage of $1-5 \mathrm{~g} / \mathrm{dm}^{3}$, and the interaction time of 3 hours, the degree of manganese ions removal was $100 \%$ [42].

Native and mercerized garlic skin was used to remove $\mathrm{Pb}^{2+}$ ions from simulated solutions. It was found that at $\mathrm{pH}=3-7, \mathrm{CPb}=10 \mu \mathrm{g} / \mathrm{sm} 3$; contact time $15 \mathrm{~min}$, the dosage of adsorbent $10 \mathrm{mg}$ the maximum sorption capacity of native garlic peel was $51.73 \mathrm{mg} / \mathrm{g}$, modified -109.05 [43].

Garlic peel (GP) was changed by cation exchange loading with Fe(III), Ti(IV), and $\mathrm{Ce}$ (III) ions, which could successfully adsorb tungstate ions under mildly acidic conditions. For Ti-GP, $h Y=1-4$ for $\mathrm{Fe}-\mathrm{GP}$, and $\mathrm{pH}=3$ for $\mathrm{Ce}-\mathrm{GP}$, the best initial $\mathrm{pH}$ for maximum adsorption of $\mathrm{W}(\mathrm{VI})$ ions was determined to be $\mathrm{pH}=1-3, \mathrm{hY}=1-4$ for $\mathrm{Fe}-\mathrm{GP}$, and $\mathrm{pH}=3$ for Ce$\mathrm{GP}$, respectively. The maximum adsorption capacity of Fe-GP, Ti-GP, and $\mathrm{Ce}-\mathrm{GP}$ at $\mathrm{pH}=2.5$ was determined to be $91.5 \mathrm{mg} / \mathrm{g}, 83 \mathrm{mg} / \mathrm{g}$, and $84 \mathrm{mg} / \mathrm{g}$ tungsten, respectively. Anions such as chloride, sulfate, and carbonate had minimal effect on tungsten adsorption, whereas fluoride and phosphate significantly impeded it. The breakthrough points for Ce-GP, Ti-GP, and Fe-GP 
were 180 minutes, 200 minutes, and 270 minutes, respectively, according to column adsorption [44].

The above information on the sorption capacity of garlic processing by-products has incomparable indicators since the experiments were carried out under different conditions. In this regard, information on sorption characteristics for metal ions conducted under the same conditions is of interest. Thus, the adsorption of $\mathrm{Cu}^{2+}$ and $\mathrm{Pb}^{2+}$ ions on garlic stalks were studied. The efficiency of the adsorbent was investigated using the batch adsorption approach under various experimental settings by altering parameters such as $\mathrm{pH}$, starting concentration, and contact time. The results reveal that $\mathrm{Pb}^{2+}$ ions have the highest adsorption capability when the $\mathrm{pH}$ is 2.03 , the adsorption temperature is $35^{\circ} \mathrm{C}$, the adsorption period is 90 minutes, and the amount of garlic stem is $1.0 \mathrm{~g}$. The maximal adsorption capacity of $\mathrm{Pb}^{2+}$ ions on the garlic stem is $28.42 \mathrm{mg} / \mathrm{g}$, with a 94.74 percent absorption rate. $\mathrm{Cu}^{2+}$ ions have the greatest adsorption at the same temperature when the $\mathrm{pH}$ is 4.05 , the adsorption time is 120 minutes, and the amount of garlic stem is 1.0. $\mathrm{Cu}^{2+}$ ions have maximum adsorption of $20.90 \mathrm{mg} / \mathrm{g}$ and a 69.75 percent adsorption rate. [45].

The viability of garlic peel (GP) to remove $\mathrm{Pb}^{2+}, \mathrm{Cu}^{2+}$, and $\mathrm{Ni}^{2+}$ ions was evaluated. Batch experiments were carried out to investigate the effects of $\mathrm{pH}$, temperature, time, and on the adsorption of a single heavy metal ion by GP, the initial metal ion concentration. Competitive adsorption of the binary mixture $\left(\mathrm{Pb}^{2+} / \mathrm{Cu}^{2+}\right.$ ions and $\mathrm{Pb}^{2+} / \mathrm{Ni}^{2+}$ ions $)$ by GP was also investigated. The results showed that the adsorption process could attain an equilibrium within $20 \mathrm{~min}$, and kinetics was found to fit the pseudo-second-order equation. GP had a remarkably higher adsorption affinity for $\mathrm{Pb} 2+$ ions than $\mathrm{Cu} 2+$ ions and $\mathrm{Ni} 2+$ ions with the maximum adsorption capacity of $209 \mathrm{mg} / \mathrm{g}$. The adsorption efficiency and uptake capacity of one metal ion were reduced by the presence of the other metal ion. The adsorption mechanism was supposed to be ion exchange between $\mathrm{Ca}^{2+}$ ions of GP with heavy metal ions in the solution [46].

At various adsorbent/metal ion ratios, garlic wastes from the market and food canning processes were employed to adsorb $\mathrm{Pb}^{2+}, \mathrm{Sn}^{2+}, \mathrm{Fe}^{2+}, \mathrm{Hg}^{2+}, \mathrm{As}^{3+}$, and $\mathrm{Cd}^{2+}$ from multicomponent systems. The effects of $\mathrm{pH}$, contact time, temperature, and the concentration of adsorbent and adsorbate on the decontamination of effluents in a batch adsorption approach were investigated in order to improve the conditions for use on a commercial scale. The experiment was carried out at $50^{\circ} \mathrm{C}$, and the results revealed that efficiencies are $\mathrm{pH}$-dependent. A second-order model was used to compute the kinetic parameters, which took 30 minutes to reach equilibrium. It is found that the maximum sorption capacity for the said metal ions can be ranked as follows: $\mathrm{Pb}^{2+}(10.47 \mathrm{mg} / \mathrm{g})>\mathrm{Fe}^{2+}(8.46 \mathrm{mg} / \mathrm{g})>\mathrm{Sn}^{2+}(7.13 \mathrm{mg} / \mathrm{g})>\mathrm{Hg}^{2+}(5.12$ $\mathrm{mg} / \mathrm{g})>\mathrm{As}^{3+}(2.30 \mathrm{mg} / \mathrm{g})>\mathrm{Cd}^{2+}(1.47 \mathrm{mg} / \mathrm{g})$. Desorption indicates a maximum $71 \%$ recovery of metal ions, making the remediation process cost-effective and reusable [47].

In addition to metal cations and metalloids, garlic processing by-products were studied as sorption materials to remove anions from aqueous media. Thus, a low-cost and effective biosorbent made from garlic peel was proposed for recovering phosphorus selectively from acid leach liquid under acidic conditions at $\mathrm{pH}=1-2$. To determine the best adsorption parameters for the model solutions, various batch experiments were conducted under various conditions, including altering $\mathrm{pH}$, contact time, adsorbent doses, and metal ion concentration. The ideal $\mathrm{pH}$ for phosphate ion adsorption was about $\mathrm{pH}=1.5$, reaching adsorption equilibrium after 240 minutes. The maximum adsorption capacity for phosphate ions was $1.40 \mathrm{mmol} / \mathrm{g}$ and $0.81 \mathrm{mmol} / \mathrm{g}$, respectively, at equilibrium $\mathrm{pH}=1.5$ and $\mathrm{pH}=6.5$. A $\mathrm{NaOH}$ solution effectively 
eluted the adsorbed phosphate ions, and the eluted solution contained mainly $\mathrm{Na}_{3} \mathrm{PO}_{4}$ and $\mathrm{NaOH}$. The garlic peel adsorbent was particularly successful in recovering phosphorus from iron ore leach liquor, and the adsorption efficiency could retain 85 percent of the original adsorption capability even after five cycles of adsorption and desorption. [48].

The efficacy of $\mathrm{Zr}(\mathrm{IV})$-loaded garlic peel in removing fluoride ions from a continuous fixed-bed column was investigated in order to provide direction for the column reactor's design and operation. On the fluorine adsorption performance, the impacts of $\mathrm{Zr}(\mathrm{IV})$ ion loading concentration, beginning $\mathrm{pH}$, initial fluoride concentration, flow rate, and bed depth were investigated. The experimental data were found to correspond well with the Thomas and bed depth service time models. Through a $0.5 \mathrm{~g} \mathrm{Zr}$ (IV)-GP column, $1.2 \mathrm{dm} 3$ clean groundwater was created to meet China's national standard $(1.0 \mathrm{mg} / \mathrm{dm} 3)$, implying that $1 \mathrm{~kg} \mathrm{Zr}$ (IV)-GP adsorbent can provide $2.4 \mathrm{~m} 3$ cleaning water. The $\mathrm{Zr}(\mathrm{IV})-\mathrm{GP}$ column may be regenerated by eluting adsorbed fluoride ions with $1 \mathrm{M} \mathrm{NaOH}$, and at least three cycles were performed to detect a slight decrease in adsorption performance. The adsorbent is affordable; a kilogram of adsorbent costs less than $\$ 0.50$. [49].

\section{Removal of Dyes and other Organic Compounds with Garlic Processing By-Products}

Studies have been conducted on the removal of dyes from aqueous solutions with garlic processing by-products. Thus, in a batch method, the ability of garlic peel (GP), an agricultural waste, to remove methylene blue (MB) from an aqueous solution was assessed. Contact period, starting concentration $\left(25-200 \mathrm{mg} / \mathrm{dm}^{3}\right), \mathrm{pH}(4-12)$, and temperature were all factors in the experiments $(303,313$, and $323 \mathrm{~K})$. The data matched the Freundlich isotherm well. At 303, 313 , and $323 \mathrm{~K}$, the maximal monolayer adsorption capacities were found to be 82.64, 123.45, and $142.86 \mathrm{mg} / \mathrm{g}$, respectively. Pseudo-first-order and pseudo-second-order models were used to assess the kinetic data. The findings suggested that garlic peel could be utilized as an alternative to more expensive adsorbents for color removal. [50].

The efficacy of garlic straw (GS) was investigated in this study as a novel adsorbent to eliminate dye molecules. With an adsorbent dosage of $0.04 \mathrm{~g}$ per $10 \mathrm{sm} 3$ and an initial dye concentration of $100 \mathrm{mg} / \mathrm{dm} 3$, more than $85 \%$ removal efficiency was achieved in less than 200 minutes. At $\mathrm{pH}=7$ and $\mathrm{T}=303 \mathrm{~K}$, the highest sorption capacity was reported to be 256.41 $\mathrm{mg} / \mathrm{g}$. The data on kinetic sorption was found to be consistent with pseudo-second-order kinetics. Calculations of various thermodynamic parameters $(\Delta \mathrm{G}=-1.532,-1.609$ and -1.737 $\mathrm{kJ} / \mathrm{mol}$ at 303,313 and $323 \mathrm{~K}, \Delta \mathrm{H}=50.367 \mathrm{~kJ} / \mathrm{mol}, \Delta \mathrm{S}=109.71 \mathrm{~J} / \mathrm{mol} \cdot \mathrm{K}$ ), show that the sorption process is endothermic and spontaneous. Desorption studies on regenerating garlic straw revealed that it has a greater desorption capacity following sorption $\mathrm{MB}$ with $\mathrm{HCl}$ at $\mathrm{pH}=2$. [51].

Three chemical modification procedures were used to modify garlic peel: oxidation with $\mathrm{H}_{2} \mathrm{O}_{2}$, acid oxidation with $\mathrm{HNO}_{3} / \mathrm{C}_{6} \mathrm{H}_{8} \mathrm{O}_{7}$, and alkaline saponification with $\mathrm{NaOH}$, respectively. Unmodified garlic peels and as-synthesized chemically modified garlic peels were thoroughly investigated and tested as biosorbents to eliminate Rhodamine $\mathrm{B}(\mathrm{RhB})$. Results showed that acid oxidation could increase surface area and acidic oxygen groups, which were beneficial for the adsorption of toxic dyes. Notably, $\mathrm{HNO}_{3}-\mathrm{GP}$ turned out to be the most efficient among the five studied garlic peels, the adsorption capacity of which was 3.5 times of unmodified-GP when the initial Rhodamine B concentration was $15 \mathrm{mg} / \mathrm{dm} 3$. It was found that the kinetics of the process follows the pseudo-second-order model $(\mathrm{R} 2=0.9999)$, 
and the adsorption isotherms at different temperatures are most accurately described by the Tyomkin model. The adsorption of Rhodamine B was $\mathrm{pH}$-dependent, and $95.8 \pm 1.1 \%$ of the adsorbed dye could be eluted by $0.1 \mathrm{~mol} / \mathrm{dm} 3 \mathrm{NaOH}$ [52].

In the next work, the efficiency and performance of garlic peel adsorbent for the removal of Direct Red 12B dye from wastewater were investigated. The pseudo-second-order kinetic model was shown to fit better with a high correlation coefficient, and the equilibrium data fitted well with the Langmuir model. More than $99 \%$ removal efficiency was obtained within $25 \mathrm{~min}$ at an adsorbent dose of $0.2 \mathrm{~g}$ per $50 \mathrm{sm} 3$ for an initial dye concentration of 50 $\mathrm{mg} / \mathrm{dm} 3$. The maximum sorption capacity calculated from the Langmuir model equation was $38 \mathrm{mg} / \mathrm{g}$. Calculation of various thermodynamic parameters $((\Delta \mathrm{G}=-95.39,-111.2,-130.16$ and $-160.91 \mathrm{~kJ} / \mathrm{mol}$ at $298,308,318$ and $328 \mathrm{~K}$, respectively, $\Delta \mathrm{H}=54.45 \mathrm{~kJ} / \mathrm{mol}, \Delta \mathrm{S}=213.621$ $\mathrm{J} / \mathrm{mol} \cdot \mathrm{K}$ ) of the on-going adsorption process indicate feasibility and endothermic nature of Direct Red 12B dye adsorption [53].

In previous research, the ability of agricultural waste garlic root to remove Malachite green (MG) from aqueous solutions was assessed. [54]. The adsorption kinetics followed the pseudo-second-order equation (R2>0.99), and the equilibrium data fit well into the Langmuir model (R2>0.99). With the addition of 1 and $2 \mathrm{~g} / \mathrm{dm} 3$ garlic root, the highest adsorption capacities of Malachite green dye onto the adsorbent were 172.41 and $232.56 \mathrm{mg} / \mathrm{g}$, respectively. The treated Malachite green dye solutions were less harmful than the parent solutions in the acute toxicity test.. These findings show that garlic root could be a low-cost adsorbent for color removal in industrial effluent. [54].

Several publications are devoted to the study of adsorption of phenol by garlic biomass processing by-products under static [55] and dynamic [56] conditions. In the course of experiments under static conditions, The following was discovered to be the ideal conditions for maximal phenol elimination from an aqueous solution containing garlic peel of $50 \mathrm{mg} / \mathrm{dm}^{3}$ $\mathrm{pH}=2,2.1 \mathrm{~g} / \mathrm{dm}^{3}$ adsorbent dosage, 7-hour contact period, and $135 \mathrm{rpm}$ agitation Batch adsorption studies were carried out under these optimal circumstances to investigate the effects of starting concentration and temperature on phenol elimination. The sorption process was discovered to be both spontaneous and exothermic. The pseudo-second-order kinetic model is used to explain the adsorption kinetics of phenol elimination by GP. The study's findings revealed that more than $80 \%$ of the phenol could be removed. [55]. According to the investigations, the procedure of removing phenol from aqueous systems using garlic peel powder may be successfully adapted to the field because it can be done in a continuous mode. Furthermore, low flow rates were found to maintain performance for longer within breakthrough limits with a greater specific rate of adsorption, increasing the efficiency of garlic peel use. [56]. It is found that the process was most accurately $(\mathrm{R} 2=0.9886)$ described by the Yoon-Nelson model.

Garlic peel has also proven itself as a good sorption material for removing antibiotics from aqueous media. Thus, the adsorption characteristics of garlic peel (GP) and $\mathrm{HN} \mathrm{O}_{3}$ modified garlic peel ( $\left.\mathrm{HN} \mathrm{O}_{3}-\mathrm{GP}\right)$ for quinolone antibiotics were compared in [57]. Comparisons of GP and $\mathrm{HN} \mathrm{O}_{3}-\mathrm{GP}$ characterizations demonstrated that increasing the surface acidic functional group of $\mathrm{HN} \mathrm{O}_{3}$-GP resulted in a considerable increase in adsorption capacity (about 10 times of GP). Furthermore, the adsorption behaviors of GP and $\mathrm{HN} \mathrm{O}_{3}-\mathrm{GP}$ for quinolone antibiotics were examined, including adsorption kinetics, isotherm, and thermodynamic investigations, with the results demonstrating that $\mathrm{HN} \mathrm{O}_{3}$-GP has a higher affinity for quinolones. [57]. 
Terbium, europium, and terbium/europium-loaded garlic peels (Tb-GP, Eu-GP, and $\mathrm{Tb} / \mathrm{Eu}-\mathrm{GP}$ ) were successfully produced and tested as biosorbents for enrofloxacin (ENR) extraction from aqueous solutions. It was shown that Tb/Eu-GP $(769 \mathrm{mg} / \mathrm{g})$ had a much higher enrofloxacin adsorption capacity than unloaded GP $(29.8 \mathrm{mg} / \mathrm{g})$ and was superior to $\mathrm{Tb}-\mathrm{GP}$ $(580 \mathrm{mg} / \mathrm{g})$ and Eu-GP (421 mg g1). Tb/Eu-GP was also found to be highly effective at $\mathrm{pH}$ values ranging from 6.0 to 8.0. Furthermore, ultrapure water containing 5\% ammonia was able to elute 98.11 .5 percent of the absorbed ENR from Tb/Eu-GP, and the reusability and regeneration tests indicated Tb/Eu-long-term GP's viability. [58].

\section{Production of Activated Carbons from Garlic Processing Waste}

One of the areas of using garlic processing by-products is the carbonation of the latter to produce activated carbons $[59,60]$. Under comprehensive batch tests, nanoporous activated garlic stem carbon (AGSC) was produced from garlic stem waste and used to remove As(III) from synthetic water. The adsorption of As(III) onto AGSC was investigated using batch adsorption studies. The ideal conditions of $\mathrm{pH} 6$, adsorbent dose $5 \mathrm{~g} / \mathrm{L}$, equilibrium period 150 min, beginning As(III) concentration $400 \mathrm{~g} / \mathrm{L}$, and temperature $298 \mathrm{~K}$ resulted in maximum removal of 93.3 percent of As(III). AGSC has a maximum adsorption capacity of $192.30 \mathrm{~g} / \mathrm{g}$ for the elimination of As(III). In comparison to Freundlich's isotherm, both Langmuir and Temkin's isotherm models suit the experimental data well. According to kinetics, the adsorption of As(III) was more suited for pseudo-second-order than pseudo-first-order and Elovich models. Weber-Morris and Boyd's mass transfer models could be used to characterize the mass transfer mechanism. As(III), adsorption onto AGSC was exothermic and spontaneous, as evidenced by the negative enthalpy and free energy change. [61].

Using $\mathrm{KOH}$ as an activator, a garlic skin-derived porous biomass carbon (GSP-BC) material with an ultra-high specific surface area was created. The GSP-BC has a surface area of $3686 \mathrm{~m} 2 / \mathrm{g}$, an average pore diameter of $2.43 \mathrm{~nm}$, and a total pore volume of $1.96 \mathrm{~cm} 3 / \mathrm{g}$, respectively. The GSP-BC has a remarkable adsorption capacity of $1911.8 \mathrm{mg} / \mathrm{g}(\mathrm{TCH})$ for tetracycline hydrochloride. The effects of critical variables such as starting concentration (300$\left.800 \mathrm{mg} / \mathrm{dm}^{3}\right)$, contact time, solution $\mathrm{pH}$ (3-10), ionic strength, and temperature (290-313 K) were studied in detail. The pseudo-second-order and Freundlich models, respectively, suit the experimental data of adsorption kinetics and isotherms well. Furthermore, the adsorption was endothermic and spontaneous. [62].

\section{Conclusions}

In paper summarized the literature data on using ground peels, outer leaves, and roots of garlic (Allium sativum L.) as sorption materials to remove various metal ions, such as $\mathrm{As}^{3+}$, $\mathrm{Cd}^{2+}, \mathrm{Cr}(\mathrm{VI}), \mathrm{Cu}^{2+}, \mathrm{Fe}^{2+}, \mathrm{Hg}^{2+}, \mathrm{Mn}(\mathrm{VII}), \mathrm{Ni}^{2+}, \mathrm{Pb}^{2+}, \mathrm{Sn}^{2+}$ and $\mathrm{W}(\mathrm{VI})$, dyes, and antibiotics from aqueous media. This paper provides brief information on the amount of waste generated from processing garlic, its chemical composition, and ways of reuse. It gives the adsorption processes parameters and the values of sorption parameters for the studied pollutants. It was shown that garlic residue sorption characteristics for various pollutants could be increased by chemical modification with various chemical reagents. It was determined that the Langmuir model more accurately describes the pollutant's adsorption isotherms in most cases, and the kinetics of the process more accurately describes the pseudo-second-order model. It was shown that garlic peels and steam are good precursors for activated carbons production. 


\section{Funding}

This research received no external funding.

\section{Acknowledgments}

This research has no acknowledgment.

\section{Conflicts of Interest}

The authors declare no conflict of interest.

\section{References}

1. Sabzehmeidani, M.M.; Sahar Mahnaee, S.; Ghaedi, M.; Hadi Heidari, H.; Roy, V.A.L. Carbon based materials: a review of adsorbents for inorganic and organic compounds. Mater. Adv. 2021, 2, 598-627, https://doi.org/10.1039/D0MA00087F.

2. Yeow, P.K.; Wong, S.W; Hadibarata, T. Removal of Azo and Anthraquinone dye by plant biomass as adsorbent-A review. Biointerface Res. ApChem. 2021, 11, 8218-8232, https://doi.org/10.33263/BRIAC111.82188232.

3. Kanthasamy, S.; Hadibarat, T.; Hidayat, T.; Alamri, S.A.; Al-Ghamdi, A.A. adsorption of azo and anthraquinone dye by using watermelon peel powder and corn peel powder: equilibrium and kinetic studies. Biointerface Res. ApChem. 2020, 10, 4706-4713, https://doi.org/10.33263/BRIAC101.706713.

4. Halysh, V.; Sevastyanova, O.; Pikus, S.; Dobele, G.; Pasalskiy, B.; Gun'ko V.M.; Kartel, M. Sugarcane bagasse and straw as low-cost lignocellulosic sorbents for the removal of dyes and metal ions from water. Cellulose. 2020, 27, 8181-8197, https://doi.org/10.1007/s10570-020-03339-8.

5. Shaikh, T.M.A. Adsorption of $\mathrm{Pb}$ (II) from wastewater by natural and synthetic adsorbents. Biointerface Res. ApChem. 2020, 5, 6522-6539, https://doi.org/10.33263/BRIAC105.65226539.

6. Chakraborty, R.; Asthana, A.; Singh, A.K.; Jain, B.; Susan, A.BH. Adsorption of heavy metal ions by various low-cost adsorbents: a review. Int. J. Environ. Analyt. Chem. 2020, 1-38, https://doi.org/10.1080/03067319.2020.1722811.

7. Chong, S.N.; Hadibarata, T. Adsorption of phenol red and remazol brilliant blue R by coconut shells (Cocos nucifera) and ambarella peels (Spondias dulcis). Biointerface Res. Appl. Chem. 2021, 11, 8564-8576, https://doi.org/10.33263/BRIAC111.85648576.

8. Shaikhiev, I.G; Sverguzova, S.V.; Galimova, R.Z.: Grechina, A.S. Using wastes of buckwheat processing as sorption materials for the removal of pollutants from aqueous media: A review. IOP Conf. Series: Mater. Science Eng. 2020, 945, 1-11, https://doi.org/10.1088/1757-899X/945/1/012044.

9. Sverguzova, S.V.; Shaikhiev, I.G.; Hunade, L. Study of modified peanut peel sorption properties relative to Fe(III) ions. IOP Conf. Series: Earth Environ. Sci. 2020, 459, 1-6, https://doi.org/10.1088/1755$1315 / 459 / 4 / 042064$

10. Shaikhiev, I.G.; Kraysman, N.V.; Sverguzova, S.V. Using cucurbits by-products as reagents for disposal of pollutants from water environments (a literature review). Biointerface Res. Appl. Chem. 2021, 11, 1268912705, https://doi.org/10.33263/BRIAC115.1268912705.

11. Shaikhiev, I.G.; Kraysman, N.V.; Sverguzova, S.V. Review of almond (Prunus dulcis) shell use to remove pollutants from aquatic environments. Biointerface Res. Appl. Chem. 2021, 11, 14866-14880, https://doi.org/10.33263/BRIAC116.1486614880.

12. Vannucchi, F.; Francini, A.; Raffaelli, A.; Sebastiani, L. Removal of multi-contaminants from water by association of poplar and Brassica plants in a short-term growth chamber experiment. Environ. Sci. Pollut. Res. 2021, 28, 16323-16333, https://doi.org/10.1007/s11356-020-11804-x.

13. Nuzul, M.I.; Karim, S.K.A. Cr(VI) ions removal from aqueous solutions using carrot residues as an adsorbent. Sci. Lett. 2019, 13, 30-36.

14. Ebrahimi, M.; Langeroodi, N.S.; Hooshmand, S. Biosorption of Fe(III) ions using carrot: equilibrium, kinetics, and statistical analysis. Protec. Metals Physical Chem. Surf. 2019, 55, 259-265, https://doi.org/10.1134/S2070205119020163.

15. Yargıç, A.Ş.; Şahin, Y.R.Z.; Özbay, N.; Önal, E. Assessment of toxic copper(II) biosorption from aqueous solution by chemically-treated tomato waste. J. Clean. Prod. 2015, 88, 152-159, https://doi.org/10.1016/j.jclepro.2014.05.087.

16. Mallampati, R.; Valiyaveettil, S. Application of tomato peel as an efficient adsorbent for water purification alternative biotechnology. RSC Advances 2012, 2, 9914-9920, https://doi.org/10.1039/c2ra21108d. 
17. Gutha, Y.; Munagapati, V.S.; Naushad, M.; Abburi, K. Removal of Ni(II) from aqueous solution by Lycopersicum esculentum (Tomato) leaf powder as a low-cost biosorbent. Desalin. Water Treat. 2015, 54, 200-208, https://doi.org/10.1080/19443994.2014.880160.

18. Ahmadpour, A.; Zabihi, M.; Bastami, R.; Tahmasbi, M.; Ayati, A. Rapid removal of mercury ion (II) from aqueous solution by chemically activated eggplant hull adsorbent. J. Appl. Res. Water Wastewater 2016, 3, 2, 236-240.

19. Darvanjooghi, M.H.K.; Davoodi, S.M.; Dursun, A.Y.; Ehsani, M.R.; Karimpour, I.; Ameri, E. Application of treated eggplant peel as a low-cost adsorbent for water treatment toward elimination of $\mathrm{Pb}^{2+}$ : Kinetic modeling and isotherm study. Adsorp. Sci. Technol. 2018, 36, 1112-1143, https://doi.org/10.1177/0263617417753784.

20. Sidhu, M.; Sama, P.; Parmar, J.; Bhatt, S.M. Biosorption of Arsenic (III) from drinking water by using low cost biosorbents derived from peels of oranges, turnip and peanut shells. Int. J. Pharmac. Res. Drug Develop. 2014, 1, 66-69.

21. Shaikhiev, I.G.; Kraysman, N.V.; Sverguzova, S.V. Onion (Allium Cepa) Processing Waste as a Sorption Material for Removing Pollutants from Aqueous Media. Biointerface Res. Appl. Chem. 2022, 12, 3173-3185, https://doi.org/10.33263/BRIAC123.31733185.

22. Takagi, H. Garlic Allium sativum L. In: Onions and allied crops. Volume 3-Biochemistry, Food science, and minor crops. Rabinowitch, H.D.; Brewster, J.L. (eds). CRC Press, Boca Raton, Fl. 1990; pp. 1-38.

23. El Mashad, H.M.; Zhang, R.; Pan, Z. Onion and garlic. In: Integrated Processing Technologies for Food and Agricultural By-Products. 2019; pp. 273-296.

24. Kallel, F.; Chaabouni, S.E. Perspective of garlic processing wastes as low-cost substrates for production of high-added value products: A review. Environ. Progress \&Sustain. Energy. 2017, 36, 1765-1777, http://dx.doi.org/10.1002/ep.12649.

25. Prasad Reddy, J.; Rhim, J.-W. Isolation and characterization of cellulose nanocrystals from garlic skin. Materials Letters 2014, 129, 20-23, https://doi.org/10.1016/j.matlet.2014.05.019.

26. Kallel, F.; Bettaieb, F.; Khiari, R.; García, A.; Bras, J.; Chaabouni, S.E. Isolation and structural characterization of cellulose nanocrystals extracted from garlic straw residues. Indust. Crops Prod. 2016, 87, 287-296, https://doi.org/10.1016/j.indcrop.2016.04.060.

27. Moreno, L.M.; Gorinstein, S.; Medina, O.J.; Palacios, J.; Mucoz, E.J. Valorization of garlic crops residues as precursors of cellulosic materials. Waste Biomass Valor. 2020, 11, 4767-4779, https://doi.org/10.1007/s12649-019-00799-3.

28. Pardede, C.; Iriany, Tambun, R.; Fitri, M.D. Husna, R. Extraction of tannin from garlic skins by using microwave with ethanol as solvent. IOP Conf. Series: Mater. Sci. Eng. 2020, 801, 1-8, https://doi.org/10.1088/1757-899X/801/1/012054.

29. Kallel, F.; Driss, D.; Bouaziz, F.; Neifer, M.; Ghorbel, R.; Chaabouni, S.E. Production of xylooligosaccharides from garlic straw xylan by purified xylanase from Bacillus mojavensis UEB-FK and their in vitro evaluation as prebiotics. Food Bioprod. Proces. 2014, 94, 536-546, https://doi.org/10.1016/j.fbp.2014.07.012.

30. Zaini, A.S.; Putra, N.R.; Idham, Z.; Md Norodin, N.S.; Rasidek, N.A.M.; Yunus, M.A.C. Mini review: extraction of allicin from Allium sativum using subcritical water extraction. IOP Conf. Series: Mater. Sci. Eng. 2020, 932, 1-9, https://doi.org/10.1088/1757-899X/932/1/012023.

31. Lara-Fiallos, M.V.; Bastidas-Delgado, L.A.; Villacreses, D.T.M.; Espín-Valladares, R.C.; Núñez-Pérez, J.; Martínez, A.P.; Vispo, N.S.; Cabrera, H.R.; Suárez, E.G.; Pais-Chanfrau, J.M. Optimization of inulin extraction from garlic (Allium sativum L.) waste using the response surface methodology. Revista de Education. 2021, 394, 1-30.

32. Lechner, B.E.; Monaldi, S. Utilization of garlic and maize wastes supplemented with olive mill waste water for Pleurotus ostreatus cultivation. Revista Mexicana de Micología 2011, 34, 17-22.

33. Deko, M.K.; Djunaidi, I.H.; Natsir, M.H. The use of garlic (Allium sativum Linn) bulb and husk powder as an organic feed additive on egg quality of laying hens. Int. Res. J. Advanced Eng. Sci. 2018, 3, 218-222.

34. Pereira, S.S.de A.A.; Pêgas, M.M.; Fernández, T.L.; Magalhães, M.; Schöntag, T.G.; Lago, D.C.; Senna, L.F.; D'Elia, E. Inhibitory action of aqueous garlic peels extract on the corrosion of carbon steel in $\mathrm{HCl}$ solution. Corrosion Sci. 2012, 65, 360-366, https://doi.org/10.1016/j.corsci.2012.08.038.

35. Bravo-Núñez, A.; Golding, M.; McGhie, T.K.; Gómez, M.; Matía-Merino, L. Emulsification properties of garlic aqueous extract. Food Hydrocolloids. 2019, 93, 111-119, https://doi.org/10.1016/j.foodhyd.2019.02.029.

36. Ifesan, B.O.T.; Fadipe, E.A.; Ifesan, B.T. Investigation of antioxidant and antimicrobial properties of garlic peel extract (Allium sativum) and its use as natural food additive in cooked beef. J. Scientific Res. Rep. 2014, 3, 711-721.

37. Kotenkova, E.A.; Kupaeva, N.V. Comparative antioxidant study of onion and garlic waste and bulbs. IOP Conf. Series: Earth Environ. Sci. 2019, 333, 1-5, https://doi.org/10.1088/1755-1315/333/1/012031.

38. Coman, V.; Teleky, B.-E.; Mitrea, L.; Martău, G.A.; Szabo, K.; Călinoiu, L.-F.; Vodnar, D.C. Chapter Five -Bioactive potential of fruit and vegetable wastes. In: Advances in Food and Nutrition Research. Toldrá, F. Ed.; Academic Press: Volume 91, 2020; pp. 157-225, https://doi.org/10.1016/bs.afnr.2019.07.001. 
39. Sun, J.; Li, X.; Ai, X.; Liu, J.; Yin, Y.; Huang, Y.; Zhou, H.; Huang, K. Efficient removal of cadmium from soil-washing effluents by garlic peel biosorbent. Environ. Sci. Pollut. Res. 2018, 25, 19001-19011, https://doi.org/10.1007/s11356-018-2109-9.

40. Parlayıc, S.; Pehlivan, E. Natural biosorbents (garlic stem and horse chesnut shell) for removal of chromium(VI) from aqueous solutions. Environ. Monit. Assess. 2015, 187, 1-10, https://doi.org/10.1007/s10661-015-4984-6.

41. Chowdhury, A.; Bhowal, A.; Datta, S. Equilibrium, thermodynamic and kinetic studies for removal of copper (II) from aqueous solution by onion and garlic skin. Water 2012, 4, 37-51, http://dx.doi.org/10.14294/WATER.2012.4.

42. Geetha, K.S.; Belagali, S.L. Removal of dyes and heavy metals using garlic husk. Nature Environ. Pollut. Technol. 2010, 9, 323-327.

43. Liu, W.; Liu, Y.; Tao, Y.; Yu, Y.; Jiang, H.; Lian, H. Comparative study of adsorption of Pb(II) on native garlic peel and mercerized garlic peel. Environ. Sci. Pollut. Res. 2014, 21, 2054-2063, https://doi.org/10.1007/s11356-013-2112-0.

44. Wang, Y.; Huang, K. Biosorption of tungstate onto garlic peel loaded with Fe(III), Ce(III), and Ti(IV). Environmental Science and Pollution Research 2020, 27, 33692-33702, https://doi.org/10.1007/s11356-02009309-8.

45. Zhou, N.; Zhou, Z.; Qin, Y.; Zeng, C.J.; Huang, Z.Q. Adsorption of two heavy metal ions on dry garlic stem. Adv. Mater. Res. 2011, 396-398, 2443-2446, https://doi.org/10.4028/www.scientific.net/AMR.396398.2443.

46. Liang, S.; Guo, X.; Tian, Q. Adsorption of $\mathrm{Pb}^{2+}, \mathrm{Cu}^{2+}$ and $\mathrm{Ni}^{2+}$ from aqueous solutions by novel garlic peel adsorbent. Desalin. Water Treat. 2013, 51, 7166-7171, https://doi.org/10.1080/19443994.2013.769919.

47. Negi, R.; Satpathy, G.; Tyagi, Y.K.; Gupta R.K. Biosorption of heavy metals by utilising onion and garlic wastes. Int. J. Environment and Pollution 2012, 49, 179-196, http://dx.doi.org/10.1504/IJEP.2012.050898.

48. Sun, J.; Xiu, Y.; Huang, K.; Yu, J.; Alam, S.; Zhua, H.; Guo, Z. Selective recovery of phosphorus from acid leach liquor of iron ore by garlic peel adsorbent. $R S C$ Adv. 2018, 8, 22276-22285, https://doi.org/10.1039/c8ra03203c.

49. Zhang, Y.; Xiong, L.; Xiu, Y.; Huang, K. Defluoridation in fixed bed column filled with Zr(IV)-loaded garlic peel. Microchem. J. 2019, 145, 476-485, https://doi.org/10.1016/j.microc.2018.11.007.

50. Hameed, B.H.; Ahmad, A.A. Batch adsorption of methylene blue from aqueous solution by garlic peel, an agricultural waste biomass. J. Hazard. Mater. 2009, 164, 870-875, https://doi.org/10.1016/j.jhazmat.2008.08.084.

51. Kallel, F.; Chaari, F.; Bouaziz, F.; Bettaieb, F.; Ghorbel, R.; Chaabouni, S.E. Sorption and desorption characteristics for the removal of a toxic dye, methylene blue from aqueous solution by a low cost agricultural by-product. J. Molec. Liq. 2016, 219, 279-288, http://dx.doi.org/10.1016/j.molliq.2016.03.024.

52. Zhao, Y.; Zhu, L.; Li, W.; Liu, J.; Liu, X.; Huang, K. Insights in to enhanced adsorptive removal of Rhodamine B by different chemically modified garlic peels: Comparison, kinetics, isotherms, thermodynamics and mechanism. J. Molec. Liq. 2019, 293, 1-10, https://doi.org/10.1016/j.molliq.2019.111516.

53. Asfaram, A.; Fathi, M.R.; Khodadoust, S.; Naraki, M. Removal of Direct Red 12B by garlic peel as a cheap adsorbent: Kinetics, thermodynamic and equilibrium isotherms study of removal. Spectrochim. Acta. Part A: Molec. Biomolec. Spectroscopy. 2014, 127, 415-421, http://dx.doi.org/10.1016/j.saa.2014.02.092.

54. Ren, H.; Zhang, R.; Wang, Q.; Pan, H.; Wang, Y. Garlic root biomass as novel biosorbents for Malachite Green removal: parameter optimization, process kinetics and toxicity test. Chem. Res. Chin. Univ. 2016, 32, 647-654, http://dx.doi.org/10.1007/s40242-016-6095-5.

55. Muthamilselvi, P.; Karthikeyan, R.; Kumar, B.S.M. Adsorption of phenol onto garlic peel: optimization, kinetics, isotherm, and thermodynamic studies. Desalination and Water Treatment 2016, 57, 2089-2103, https://doi.org/10.1080/19443994.2014.979237.

56. Muthamilselvi, P.; Karthikeyan, R.; Kapoor, A.; Prabhakar, S. Continuous fixed-bed studies for adsorptive remediation of phenol by garlic peel powder. Int. J. Indust. Chem. 2018, 9, 379-390, https://doi.org/10.1007/s40090-018-0166-z.

57. Zhao, Y.; Li, W.; Liu, J.; Huang, K.; Wu, C.; Shao, H.; Chen, H.; Liu, X. Modification of garlic peel by nitric acid and its application as a novel adsorbent for solid-phase extraction of quinolone antibiotics. Chem. Eng. J. 2017, 326, 745-755, http://dx.doi.org/10.1016/j.cej.2017.05.139.

58. Zhao, Y.; Li, W.; Liu, Z.; Liu, J.; Zhu, L.; Liu, X.; Huang, K. Renewable Tb/Eu-loaded garlic peels for enhanced adsorption of enrofloxacin: kinetics, isotherms, thermodynamics, and mechanism. ACS Sustainable Chem. Eng. 2018, 6, 15264-15272, http://dx.doi.org/10.1021/acssuschemeng.8b03739.

59. Huang, G.; Wu, X.; Hou, Y.; Cai, J. Sustainable porous carbons from garlic peel biowaste and KOH activation with an excellent $\mathrm{CO}_{2}$ adsorption performance. Biomass Convers. Biorefin. 2020, 10, 267-276, https://doi.org/10.1007/s13399-019-00412-6.

60. Roy, P.; Bhat, V.S.; Saha, S.; Sengupta, D.; Das, S.; Datta, S.; Hegde, G. Mesoporous carbon nanospheres derived from agro-waste as novelantimicrobial agents against gram-negative bacteria. Environ. Sci. Pollut. Res. 2021, 28, 13552-13561, https://doi.org/10.1007/s11356-020-11587-1. 
61. Prajapati, A.K.; Mondal, M.K. Hazardous As(III) removal using nanoporous activated carbon of waste garlic stem as adsorbent: Kinetic and mass transfer mechanisms. Korean J. Chem. Eng. 2019, 36, 1900-1914, http://dx.doi.org/10.1007/s11814-019-0376-X.

62. Liu, S.; Pan, M.; Feng, Z.; Qin, Y.; Wang, Y.; Tanc, L.; Sun, T. Ultra-high adsorption of tetracycline antibiotics on garlic skin-derived porous biomass carbon with high surface area. New J. Chem. 2020, 44, 1097-1106, http://dx.doi.org/10.1039/c9nj05396d. 